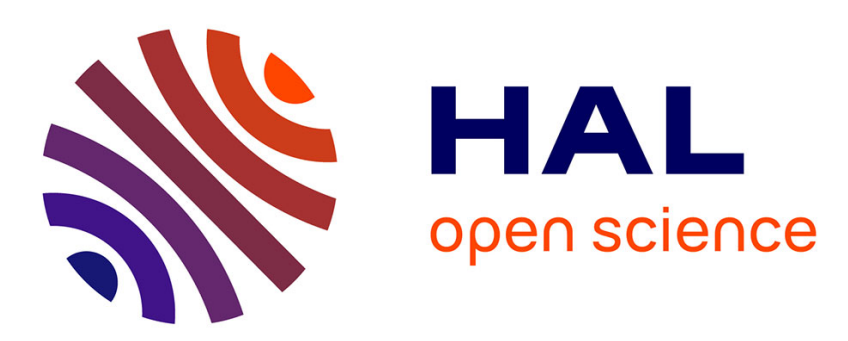

\title{
Characterization of Brazilian Peat Samples by Applying a Multi-Method Approach
}

F. Girardello, Régis Guégan, Valdemar I. Esteves, I.J.R. Baumvol, M.M.D. Sierra, J.S. Crespo, A.N. Fernandes, M. Giovanela

\section{- To cite this version:}

F. Girardello, Régis Guégan, Valdemar I. Esteves, I.J.R. Baumvol, M.M.D. Sierra, et al.. Characterization of Brazilian Peat Samples by Applying a Multi-Method Approach. Spectroscopy Letters: An International Journal for Rapid Communication, 2013, 46 (3), pp.201-210. 10.1080/00387010.2012.702184 . insu-00751322

\section{HAL Id: insu-00751322}

\section{https://hal-insu.archives-ouvertes.fr/insu-00751322}

Submitted on 16 Nov 2012

HAL is a multi-disciplinary open access archive for the deposit and dissemination of scientific research documents, whether they are published or not. The documents may come from teaching and research institutions in France or abroad, or from public or private research centers.
L'archive ouverte pluridisciplinaire HAL, est destinée au dépôt et à la diffusion de documents scientifiques de niveau recherche, publiés ou non, émanant des établissements d'enseignement et de recherche français ou étrangers, des laboratoires publics ou privés. 
Characterization of Brazilian peat samples by applying a multi-method approach

F. Girardello ${ }^{\mathrm{a}}$, R. Guégan ${ }^{\mathrm{b}}$, V. I. Esteves ${ }^{\mathrm{c}}$, I. J. R. Baumvol ${ }^{\mathrm{a}, \mathrm{d}}$, M. M. D. Sierra ${ }^{\mathrm{e}}$, J. S. Crespo $^{\mathrm{a}}$, A. N. Fernandes ${ }^{\mathrm{f}}$, M. Giovanela ${ }^{\mathrm{a}, *}$

${ }^{a}$ Centro de Ciências Exatas e Tecnologia, Universidade de Caxias do Sul, 95070-560 Caxias do Sul - RS, Brazil.

${ }^{\mathrm{b}}$ Institut des Sciences de la Terre, Université d'Orléans, CNRS UMR 6113, Université d'Orléans, 45071 Orléans Cedex 2, France

${ }^{c}$ CESAM \& Departamento de Química (Centro de Estudos do Ambiente e do Mar), Universidade de Aveiro, 3810-193, Aveiro - Portugal

${ }^{\mathrm{d}}$ Instituto de Física, Universidade Federal do Rio Grande do Sul, 91509-900 Porto Alegre RS, Brazil

e Departamento de Química, Universidade Federal de Santa Catarina, 88040-900,

Florianópolis - SC, Brazil

${ }^{\mathrm{f}}$ Instituto de Química, Universidade Federal do Rio Grande do Sul, 91501-970 Porto Alegre, RS - Brazil

*E-mail address: mgiovan1@ucs.br (M. Giovanela). 


\begin{abstract}
Peat is a mixture of compounds formed by the decomposition of plant residues and mineral materials that have accumulated at the bottom of ponds and flooded depressions in riverine areas. Due to their extreme heterogeneity and natural variety, the physical and chemical properties of peat can vary widely within or between deposits, and the characterization of isolated samples is still a challenging task that requires the combination of several chemical and spectroscopic methodologies. In this study, the structural characteristics of two Brazilian peat samples were evaluated using scanning electron microscopy (SEM), elemental (CHNS-O) and thermal (TGA) analysis, X-ray diffraction (XRD), and infrared (FT-IR) and solid-state ${ }^{13} \mathrm{C}$ nuclear magnetic resonance $\left({ }^{13} \mathrm{C} \mathrm{NMR}\right)$ spectroscopies. Although the samples originated from the same peatland, the data showed that the studied samples have distinct chemical properties and that the stage of decomposition played an important role in the differences observed.
\end{abstract}

Key words: Peat; Morphological Analysis; Spectroscopic Characterization 


\section{Introduction}

Organic matter (OM) found in the environment (soil, peat, sediments, water, atmospheric aerosols) plays a crucial role in the chemical and physical processes of its surrounding region. OM performs a central role in the fate of anthropogenic contaminants, acting as adsorbents, ligands, and catalysts in redox and photochemical reactions. Thus, it is generally recognized that the identification and characterization of $\mathrm{OM}$ components is essential for understanding its chemical and geochemical processes [1-3].

Peat is an organic material $(<25 \%$ by weight mineral matter $)$ that ranges in color from blond to black and is usually formed in regions where there is a lack of oxygen and where the accumulation of OM occurs more rapidly than its decomposition [2, 4-6]. Under these conditions, a deposit of OM can reach thicknesses of several meters and occupy large areas, constituting a peatland.

More than $90 \%$ of peatlands are located in temperate and cold regions. These regions compose a significant portion of the land surface in many regions of the world, with mineable resources totaling over one billion metric tons [7]. The largest peat deposits are found in the Northern Hemisphere, but significant reserves have been discovered in Brazil, Indonesia, and other subtropical regions. In Brazil, specifically, peat deposits are primarily found in coastal and river floodplains with reserves located in the Santa Catarina and Rio Grande do Sul states.

These materials are composed mainly of lignin, cellulose, and humic substances, presenting functional groups such as carboxylic acids and phenolic or alcoholic hydroxyls which improve the adsorption of organic molecules and the complexation of metal ions [7-10]. In light of these characteristics, peat represents a powerful natural adsorbent for the 
remediation of contaminated waters and may feature other analytical applications [8]. Thus, due to their extreme heterogeneity and natural variety, the chemical properties of peat can vary widely among different deposits, and the characterization of isolated peat samples and their manifold effects remains a challenging task in environmental analytical chemistry, requiring efficient combinations of several chemical and spectroscopic methodologies.

Several methods have been proposed for the classification of peat [11-14]. The method of von Post [14], which is the most widely used, classifies peat using a simple hand-squeeze test and an examination of the material to describe the wetness, level of decay, and the fiber and shrub constituents. The level of decomposition of the material is classified by determining a humification number $\left(\mathrm{H}_{\mathrm{n}}\right)$ between 1 and 10, where $\mathrm{H}_{1}$ refers to a peat that has undergone no decomposition and $\mathrm{H}_{10}$ is a peat that is completely decomposed.

This method, although it is still widely used, particularly in northern Europe, suffers from two shortcomings. First, it is subjective in its application, and second, there are too many described categories. However, modern classification systems, including soil taxonomy, have adopted the principle of using decomposition stages to characterize peat materials. In soil taxonomy, the von Post scale has been narrowed down to three stages, namely the fibric, hemic and sapric types, which are quantitatively defined by the analysis of fiber content and size to remove the subjective bias [15]. Other morphological criteria, including the color, amount of mineral matter, structure and thickness of the deposits, are used in modern systems to characterize peat.

In this sense, the aim of the present paper is to describe the structural properties of two peat samples which were collected from a peatland located in the southern coastal zone of 
Brazil. The analysis was carried out by applying a new multi-method approach, including scanning electron microscopy (SEM), elemental (CHNS-O) and thermal (TGA) analysis, X-ray diffraction (XRD), and infrared (FT-IR) and solid-state ${ }^{13} \mathrm{C}$ nuclear magnetic resonance $\left({ }^{13} \mathrm{C}\right.$ NMR) spectroscopies.

\section{Material and methods}

\subsection{Study area and sampling}

The studied peat samples were collected from a peatland situated in the municipality of Balneário Arroio do Silva (Santa Catarina State, southern Brazil) (Fig. 1) by scraping at approximately $10 \mathrm{~cm}$ below the soil surface with the help of an aluminum shovel. The two sampling points are situated in a region where the incidence of vegetation is dominated mainly by mosses and other bryophytes, sedges, grasses, shrubs and small-sized trees.

The preliminary classification of the samples was carried out in situ using the method proposed by von Post (1924). According to this author, the first sample (named PS-1) was classified as $\mathrm{H}_{7}$ (presence of material with very faintly recognizable plant structure. When squeezed, about one-half of the peat escaped between the fingers. The water released was very dark and almost pasty) and the second sample (named PS-2) as $\mathrm{H}_{3}$ (when squeezed, released muddy brown water, but from which no peat passed between the fingers. Moreover, plant residues remain still identifiable), respectively.

After sampling, the peat samples were stored in air-sealed plastic bags at $10^{\circ} \mathrm{C}$. Upon reaching the laboratory, the material was freeze-dried at $-40{ }^{\circ} \mathrm{C}$ during 7 days, being subsequently placed in a vacuum oven at $25^{\circ} \mathrm{C}$ until a constant mass was achieved. This 
drying step is very important prior to the analysis since the peat usually has a high water retention capacity.

\subsection{Scanning electron microscopy (SEM)}

The SEM images of PS-1 and PS-2 samples were obtained with a Shimadzu SM4-550 scanning electron microscope operating at $15 \mathrm{keV}$. The peat samples were previously coated with a thin gold layer in a diode sputtering system for $10 \mathrm{~min}$ before analysis.

\subsection{Elemental analysis (CHNS-O) and ash content}

The elemental composition of PS-1 and PS-2 samples was determined using a Carlo Erba 1100 CHNS elemental analyzer. Relative quantities of C, H, N and S were measured directly with the analyzer. Oxygen contribution was estimated as the difference between $100 \%$ and the summed concentrations of $\mathrm{C}, \mathrm{H}, \mathrm{N}$ and $\mathrm{S}$.

The ash content was determined by ignition of peat samples $(\sim 1.0 \mathrm{~g})$ at $550{ }^{\circ} \mathrm{C}$ for $4 \mathrm{~h}$. In both cases (elemental analysis and ash content), the peat samples were analyzed in triplicate.

\subsection{Thermogravimetric analysis (TGA)}

TGA curves were recorded using a Shimadzu TGA-50 thermogravimetric analyzer. The PS-1 and PS-2 samples ( 10 mg) were placed in platinum crucibles and heated continuously from $25{ }^{\circ} \mathrm{C}$ to $900{ }^{\circ} \mathrm{C}$ under an atmosphere of nitrogen (gas flow $50 \mathrm{~mL} \mathrm{~min}{ }^{-1}$ ) at a heating rate of $10{ }^{\circ} \mathrm{C} \mathrm{min}^{-1}[16]$. 


\subsection{X-ray diffraction (XRD)}

XRD measurements were performed on representative powdered peat samples using a Shimadzu XRD-6000 X-ray diffractometer operating at $40 \mathrm{kV}$ and $30 \mathrm{~mA}$. Diffraction data were collected at room temperature in the Bragg-Brentano $\theta-2 \theta$ geometry with $\mathrm{CuK} \alpha$ radiation $(\lambda=1.54056 \AA)$. The scanning covered the $5-80^{\circ}$ range with step angle of $0.05^{\circ}$ and an integration time of $1.5 \mathrm{~s}$.

\subsection{Fourier-transform infrared spectroscopy (FT-IR)}

FT-IR spectra were recorded on a Thermo Scientific Nicolet IS10 spectrophotometer with a resolution of $4 \mathrm{~cm}^{-1}$ from 4,000 to $400 \mathrm{~cm}^{-1}$. Pellets were prepared by pressing a mixture of $5 \mathrm{mg}$ of peat sample and $95 \mathrm{mg}$ of $\mathrm{KBr}$ (spectroscopy grade) [17].

\subsection{Solid-state CP-MAS ${ }^{13} \mathrm{C}$ nuclear magnetic resonance $\left({ }^{13} \mathrm{C}\right.$ NMR) spectroscopy}

The solid-state ${ }^{13} \mathrm{C}$ NMR spectra for the PS-1 and PS-2 samples were obtained with a Brucker AMX $500 \mathrm{MHz}$ Avence spectrometer operating at a frequency of $125.75 \mathrm{MHz}$ and using approximately $100 \mathrm{mg}$ of sample in a $4 \mathrm{~mm}$ rotor. The contact time was $1 \mathrm{~ms}$, and the repetition time was $5 \mathrm{~s}$. Sample spinning at the magic angle was carried out at a frequency of $7 \mathrm{kHz}$, and a $90^{\circ}$ pulse width $(4 \mu \mathrm{s})$ was applied to the protons. The techniques of cross-polarization/magic angle spinning (CP-MAS) were used in all sequences to obtain spectra with an optimal resolution. Each spectrum contains approximately 20,000 transients. The reference at 0 ppm was set using $\mathrm{Si}\left(\mathrm{CH}_{3}\right)_{4}$. Chemical shifts were assigned according to Swift [17]: alkyl-C from 0 to $65 \mathrm{ppm}$; O-alkyl-C from 65 to $110 \mathrm{ppm}$; aromatic-C from 110 to 
$140 \mathrm{ppm}$; phenolic-C from 140 to $160 \mathrm{ppm}$; carboxylic-C from 160 to $190 \mathrm{ppm}$ and carbonyl-C from 190 to $220 \mathrm{ppm}$.

Prior to obtaining ${ }^{13} \mathrm{C}$ NMR spectra, the peat samples were purified using the method adapted by Skjemstad and collaborators [18] in order to remove any paramagnetic compounds and to dissolve the hard acid species that could be present in the structure of the samples. This procedure consisted of seven successive treatments with a $2 \%(\mathrm{v} / \mathrm{v})$ aqueous solution of HF. Each treatment involved shaking approximately $5 \mathrm{~g}$ of the sample in $50 \mathrm{~mL}$ of the acid solution for $1 \mathrm{~h}$ (six times) and then $24 \mathrm{~h}$ (once). Between treatments, the samples were centrifuged, and the supernatant was discarded and replaced with a new acid solution. In the final treatment, the peat samples were washed with deionized water and then dried using the same procedure described in the section "Study Area and Sampling".

\section{Results and discussion}

\subsection{Morphological Analysis}

Peat morphologic characterization by SEM has frequently been described in the literature [19-22]. In general, the observed material is an assemblage of decaying plant cellular structures interconnected with frequent fibers in a less decayed state. In this study, the samples were investigated to analyze the distribution and dispersion of particles and the surface morphology of these natural adsorbents. The SEM micrographs of the PS-1 and PS-2 samples are shown in Figs. 2 and 3, respectively. At a low magnification level (Fig. 2a and 3a), the two peat samples exhibited similar morphologies and comprised particles of varying sizes (from 5 to $150 \mu \mathrm{m}$ ) and thickness ( 2 to $50 \mu \mathrm{m}$ ). 
Regarding the aggregation levels, the major differences can be better detected when the SEM micrographs are observed at relatively high magnifications (Fig. 2b and 3b). In this case, it can be verified that the PS-1 aggregates are highly compact, with a globular-like structure, while the PS-2 aggregates show a predominant fiber-like structure. This latter structure (in the specific case of the PS-2 sample) is in agreement with its classification (von Post, 1924), where the plant remains may be recognizable.

Finally, a closer view of the SEM images (Fig. 2c and 3c) reveals that the elementary structures present in the surface of the PS-2 sample (Fig. 3c) are significantly connected, creating a type of open cellular structure, and that has not been evidenced in the PS-1 sample.

\subsection{Elemental analysis}

The elemental composition, atomic ratios $(\mathrm{H} / \mathrm{C}$ and $\mathrm{C} / \mathrm{N})$ and ash contents of the studied peat samples are shown in Table 1 . The values obtained here were, in general, within the ranges reported in the literature $[4,8,20,23,24]$. The PS-1 sample had higher percentages of nitrogen and oxygen, while PS-2 had a greater concentration of carbon and hydrogen.

Due to their complexity, information on the elemental composition of $\mathrm{OM}$ is not especially conclusive, and the atomic ratios have been preferentially employed in peat studies. The H/C ratio has frequently been associated with the degree of aromaticity, lower H/C values indicate a greater quantity of aromatic moieties in the peat core $[4,23,25]$. As can be observed (Table 1), the $\mathrm{H} / \mathrm{C}$ ratios were slightly different between the two samples, suggesting a greater proportion of condensed structures in the PS-2 sample, and consequently a greater quantity of aromatic structures, in relation to the PS-1 sample. The PS-2 sample, being a more recent 
material (i.e., less decomposed), is composed mainly of lignin-derived residues that have not been fully degraded.

The $\mathrm{C} / \mathrm{N}$ ratio, on the other hand, has been considered an index of the possible microbial activity because microbial communities need at least a $\mathrm{C} / \mathrm{N}$ ratio of 30.0 to carry out the organic material decomposition [24]. Kuhry and Vitt [26], in fact, showed that decreased $\mathrm{C} / \mathrm{N}$ ratios indicate increased peat decomposition and vice versa. Following this reasoning, the data in Table 1 confirm that the PS-1 sample is more decomposed than PS-2 sample, the $\mathrm{N}$ enrichment in the PS-1 sample being related to a greater incidence of microorganisms, including bacteria, fungi, and actnomycetes, at this stage of decomposition $[24,26]$.

Finally, the elemental analysis results reinforce the hypothesis that the peat samples of this work likely originate from vascular plant material rather than algal or bacterial. As previously mentioned, the sampling sites receive OM mostly from terrestrial sources, and for this reason, these trends were expected.

\subsection{Thermal analysis}

The mean progression of the combustion profile and the limits of different temperature ranges delineating the phases of thermal degradation of PS-1 and PS-2 samples are shown in Fig. 4. The results concerning the weight loss and the residual mass at $900{ }^{\circ} \mathrm{C}$ are contained in Table 2.

As can be observed, the profiles are similar between the two studied peats. In general, thermal degradation proceeds through three main steps. The first stage occurs in the 
temperature range of $25-155^{\circ} \mathrm{C}$ and corresponds to the dehydration of these materials, being accompanied by an average weight loss of approximately $2.0 \%$.

The second stage can be observed in the temperature range of $155-380{ }^{\circ} \mathrm{C}$, which is accompanied by weight losses of approximately $24 \%$. The temperature value corresponding to the peak that appears in this region was also similar for both peat samples. According to several authors [4, 27-29], this peak is considered to be the result of thermal combustion of polysaccharides, decarboxylation of acidic groups, dehydration of hydroxylate aliphatic structures and the generation of low molecular weight alcohols.

In the third stage, the PS-1 and PS-2 samples showed a "discrete" peak at $432.8^{\circ} \mathrm{C}$ and $425.8{ }^{\circ} \mathrm{C}$, which was accompanied by weight losses of $20.4 \%$ and $25.1 \%$, respectively. This thermal event has been frequently related to the degradation of aromatic structures and cleavage of $\mathrm{C}-\mathrm{C}$ bonds which are more resistant to thermal degradation $[27,30]$. In the samples studied, the weight loss associated with this region suggests a more aromatic character for the PS-2 sample. The results observed in the second and third stages of thermal degradation seem also to be corroborated by the elemental analysis.

At higher temperatures (above $615^{\circ} \mathrm{C}$ ), it can be noted that peat samples displayed no prominent peaks. The weight loss remains steady, without further observable features, until the highest temperature was reached. The residual mass at $900{ }^{\circ} \mathrm{C}$ was higher for PS-1 (42.3\%), as this sample has a large amount of mineral compounds (as quartz, feldspar and clay) in its structure. This finding was corroborated by XRD and FT-IR data, which revealed a remarkably high presence of these materials in this sample. 
The slight variability associated with the weight loss values for the two samples from the same origin is probably related to the environmental conditions and type of organic material that occur during decomposition. All these variables can markedly alter the structure and physico-chemical features of peat samples.

\subsection{XRD analysis}

Detailed examination of the mineralogy of peat samples using XRD is shown in Fig. 5. The diffractogram of the PS-2 sample shows a wide hump between $10^{\circ}$ and $30^{\circ}$, highlighting the amorphous matter that includes vitreous phases and gels [31]. The amorphous nature of this peat sample is in agreement with its earlier degree of decomposition, as it is composed of residual matter plant, decay products, and other substances produced mainly by bacteria [32].

The diffractogram of the PS-1 sample, on the other hand, reveals several sharp diffraction peaks superimposed on a background. The mineral phase analysis of the Bragg peaks shows that the major minerals in the PS-1 sample are quartz, feldspar (K-spar and Anorthite) and clay. This finding is consistent with those observed for peat samples from other sources [31] and is supported by the FT-IR analysis of this sample.

In general, powder XRD allows for the identification of crystalline phases that compose more than $5-10 \%$ of the soil. Minor soil constituents, such as iron oxides and hydroxides, and amorphous phases can be detected by XRD of a whole soil sample, but their identification is not evident, as in the case of these peat samples.

\subsection{FT-IR spectroscopy}


The application of FT-IR spectroscopy to solid organic phases provides information about the nature, reactivity, and structural arrangement of oxygen-containing functional groups, the occurrence of protein and carbohydrate constituents, the relative proportions of aromatic versus aliphatic moieties, the presence or absence of inorganic impurities, and the evolution of organic materials with depth $[9,33]$.

Fig. 6 shows the FT-IR spectra of the studied peat samples. Both spectra are characterized by a number of absorption bands that exhibit variable relative intensities, typical of natural OM $[9,23,24,33,34]$. It can be also observed that the spectra of the two peat samples are very similar; however, some slight differences become evident when these spectra are analyzed in detail mainly in the region between 1200 and $400 \mathrm{~cm}^{-1}$. FINALIZAR DE ACORDO COM O REVISOR 2!

A broad band at approximately $3400 \mathrm{~cm}^{-1}$, which is generally ascribed to $\mathrm{O}-\mathrm{H}$ and $\mathrm{N}-\mathrm{H}$ stretching of various functional groups, is present in both spectra being very similar for the two samples. This behavior was also been observed in relation to the absorption bands that appear in the region between 2920 and $2850 \mathrm{~cm}^{-1}$ and which are associated with asymmetric and symmetric $\mathrm{C}-\mathrm{H}$ stretching of the $\mathrm{CH}_{3}$ and $\mathrm{CH}_{2}$ groups of aliphatic hydrocarbons $[9,23$, 24, 33], respectively. According to Chapman and collaborators [35], these functional groups are present in the main components of waxes of terrestrial vascular plants.

The third feature found in the FT-IR spectra is related to the two absorption bands at approximately 1720 and $1620 \mathrm{~cm}^{-1}$. The first band, which is similar in both samples, has been attributed to the $\mathrm{C}=\mathrm{O}$ stretching of carbonyl functions, particularly aldehydes, ketones and carboxyl groups. The second band, on the other hand, has frequently been ascribed to $\mathrm{C}=\mathrm{C}$ 
bonds of the aromatic rings $[9,23,24,33]$, being much more pronounced in the spectrum of the PS -2 , suggesting a greater amount of lignin-like residues and consequently a great amount of aromatic moieties in its structure in relation to PS-1 sample. This result is also supported by elemental analysis and TGA data.

Another interesting difference is associated with the small and discrete absorption band occurring at approximately $1515 \mathrm{~cm}^{-1}$. As seen in Fig. 6, this band is better defined in the spectrum of the PS-2 sample, being only a very weak shoulder in the spectrum of the PS-1 sample. The same has been assigned to aromatic skeletal vibrations, usually related to lignin-like residues [33]. As revealed by SEM analysis, the PS-2 structure contains a greater amount of plant tissues that are not completely degraded, which may explain this tendency.

In the region between 1450 and $1230 \mathrm{~cm}^{-1}$, where the absorption bands are due to $\mathrm{O}-\mathrm{H}$ deformations of phenolic and aliphatic groups and $\mathrm{C}-\mathrm{O}$ stretching of ethers and/or carboxyl groups [9, 23, 24, 33], there are no relevant differences between the two samples.

Examining the region between 1070 and $1030 \mathrm{~cm}^{-1}$, the PS-1 sample shows a strong band at approximately $1035 \mathrm{~cm}^{-1}$. This assignment has been generally attributed to the $\mathrm{C}-\mathrm{O}$ stretching of polysaccharide or polysaccharide-like substances and the $\mathrm{Si}-\mathrm{O}$ stretching of silicate impurities [9, 23, 24, 33]. Likely, in the PS-1 sample, this band has a direct correlation with impurities like silicate, as the diffraction peaks for this kind of compounds were observed in the XRD analysis. This impurity content in peat samples depends on its degree of decomposition. There are two explanations for the elevated silicate content in highly decayed peat. The first explanation is that the more effective the breakdown of OM, the greater the enrichment of inorganics in the peat itself. The second explanation is that more 
decomposed peat grows with a slower rate [33]. This result is also corroborated by the bands that appear in the region between 900 and $450 \mathrm{~cm}^{-1}$ in the spectrum of the PS-1 sample (Fig. 6), which are typically associated with $\mathrm{Al}-\mathrm{Al}-\mathrm{OH}\left(914 \mathrm{~cm}^{-1}\right), \mathrm{Al}-\mathrm{O}-\mathrm{Si}\left(531 \mathrm{~cm}^{-1}\right)$ and $\mathrm{Si}-\mathrm{O}-\mathrm{Si}\left(467 \mathrm{~cm}^{-1}\right)$ deformation and $\mathrm{Si}-\mathrm{O}$ stretching $\left(795,779\right.$ and $\left.691 \mathrm{~cm}^{-1}\right)$ vibrations in clay minerals and oxides [36], indicating a larger contribution of the mineral matrix in this sample.

In summary, these results are all consistent with the presence of cellulosic, hemi-cellulosic, lignocellulosic, and lignin-derived structures as well as other by-products derived from plant materials at various stages of decomposition in the peat core of the two samples.

\section{$2.6{ }^{13} \mathrm{C}$ NMR spectroscopy}

The ${ }^{13} \mathrm{C}$ NMR spectra of the peat samples are shown in Fig. 7. In a general way, the spectra show similar characteristics, presenting signals that can be associated with the different functional aliphatic $\left(\mathrm{C}-\mathrm{H}, \mathrm{C}-\mathrm{N}, \mathrm{O}-\mathrm{CH}_{3}\right.$, polysaccharides $)$ and aromatic $(\mathrm{C}-\mathrm{H}$ and phenolic groups). The observed peaks have been frequently reported by other researchers who have used ${ }^{13} \mathrm{C}$ NMR to study and characterize different types of OM [1, 16, 23, 26, 37, 38].

The use of CP and MAS techniques resulted in spectra that were better resolved, thus allowing their division into six main regions that were assigned to alkyl-C $\left(\mathrm{R}_{1}=0-65\right.$ ppm); O-alkyl-C $\left(\mathrm{R}_{2}=65-110 \mathrm{ppm}\right)$; aromatic-C $\left(\mathrm{R}_{3}=110-140 \mathrm{ppm}\right)$; phenolic-C $\left(\mathrm{R}_{4}=\right.$ $140-160 \mathrm{ppm})$; carboxyl-C $\left(\mathrm{R}_{5}=160-190 \mathrm{ppm}\right)$; and carbonyl-C $\left(\mathrm{R}_{6}=190-220 \mathrm{ppm}\right)[16$, $23,27]$. The relative areas of the different carbon classes that were present in the studied 
samples are shown in Table 3.

The aliphatic $\mathrm{C}$ region $\left(\mathrm{R}_{1}\right)$ is dominated by the peaks at 18, 30, 33 and $55 \mathrm{ppm}$, which arise from the alkyl carbon components, such as methyl, methylene, and methine carbons. The peak centered at $33 \mathrm{ppm}$ is well defined and prominent in both spectra, suggesting a relatively high amount of aliphatic components in their structures. The well-resolved peaks at 18 and 55 ppm in the PS-2 ${ }^{13} \mathrm{C}-\mathrm{NMR}$ spectrum have been frequently associated with the terminal methyl groups and methoxy groups of lignin, respectively $[1,39]$. This result is also corroborated by the elemental analysis and FT-IR spectra.

In the O-substituted alkyl C region $\left(\mathrm{R}_{2}\right)$, two well-resolved peaks at 72 and $104 \mathrm{ppm}$ are evident in the spectra of the peat samples. The peak at $72 \mathrm{ppm}$ is thought to correspond to the carbon rings of polysaccharides, and the signal at $104 \mathrm{ppm}$ has been attributed to anomeric carbons in polysaccharides [23, 40]. This latter resonance may also indicate the non-protonated aromatic carbons in tannins [41]. The percentage of O-substituted alkyl C in this region was similar to PS-1 and PS-2 samples.

In the $110-140$ ppm region $\left(\mathrm{R}_{3}\right)$, the peaks at 116 and $129 \mathrm{ppm}$ have been attributed to unsaturated carbons or to aryl-C with protonated aromatic carbons $[16,23,27]$. The values found in this study (11.1\% for the PS-1 and $14.8 \%$ for the PS-2) were relatively low and show that the PS-2 sample has a higher degree of aromaticity, which is also corroborated by the band observed in the FT-IR spectrum at $1515 \mathrm{~cm}^{-1}$. As mentioned above, this band is related to the vibrations of the aromatic skeletal vibrations, usually related to lignin-residues, confirming that the OM present in the PS-2 sample is more recent (i.e., less decomposed) than that in the PS-1 sample. 
In the regions between $160-190 \mathrm{ppm}\left(\mathrm{R}_{5}\right)$ and $190-220 \mathrm{ppm}\left(\mathrm{R}_{6}\right)$, all peat samples exhibit a peak at approximately $172 \mathrm{ppm}$, which is characteristic of carboxyl, amide and ester functionalities $[16,23,27]$. The percentage of $\mathrm{C}$ in this region is higher for the PS-1 sample than the PS-2 sample, indicating once again that the OM in the PS-2 is at a less advanced stage of decomposition than in the PS-1 sample. All of these results are consistent with data from the elemental, thermal and infrared analyses.

\section{Conclusions}

We investigated and characterized two peat samples which were collected from a peatland situated in the Santa Catarina State (southern Brazil).

The results obtained by a multi-method approach using SEM, CHNS-O, TGA, and XRD, FT-IR and ${ }^{13} \mathrm{C}$ NMR spectroscopies are basically in agreement with each other, and indicated that PS-1 sample is more decomposed than PS-2 sample.

Although the samples originated from the same peatland, the data showed that they have distinct structural characteristics due to variable inorganic and organic material contents and, consequently, to their degree of decomposition.

\section{Acknowledgment}

This work was supported by the Coordenação de Aperfeiçoamento de Pessoal de Nível Superior (CAPES).

\section{References}


[1] Mao, J.; Chen, N.; Cao, X. Characterization of humic substances by advanced solid state NMR spectroscopy: Demonstration of a systematic approach. Organic Geochemistry 2011, 42(8), 891-902.

[2] Zhong, J.; Sleighter, R. L.; Salmon, E.; McKee, G. A.; Hatcher, P. G. Combining advanced NMR techniques with ultrahigh resolution mass spectrometry: A new strategy for molecular scale characterization of macromolecular components of soil and sedimentary organic matter. Organic Geochemistry 2011, 42(8), 903-916.

[3] Schindler, F. V.; Mercer, E. J.; Rice, J. A. Chemical characteristics of glomalin-related soil protein (GRSP) extracted from soils of varying organic matter content. Soil Biology and Biochemistry 2007, 39(1), 320-329.

[4] Fernandes, A. N.; Girardello, F.; Esteves, V. I.; Sierra; M. M. D.; Giovanela, M. Structure and Properties of Subtropical Brazilian Peat Samples. In Peat: Formation, Uses and Biological Effects; Draguhn, C.; Ciarimboli, N., Eds.; Nova Science Publishers: New York, 2012, 125-142.

[5] Fong, S. S.; Mohamed, M. Chemical characterization of humic substances occurring in the peats of Sarawak, Malaysia. Organic Geochemistry 2007, 38(6), 967-976.

[6] Viraraghavan, T.; Ayyaswami, A. Use of a peat in water pollution control: a review. Canadian Journal of Civil Engineering 1987, 14(2), 230-233.

[7] Brown, P. A.; Gill, S. A.; Allen, S. J. Metal removal from wastewater using peat. Water Research 2000, 34(16), 3907-3916.

[8] Gonzáles, A. P. S.; Firmino, M. A.; Nomura, C. S.; Rocha, F. R. P.; Oliveirac, P. V.; Gaubeur, I. Peat as a natural solid-phase for copper preconcentration and 
determination in a multicommuted flow system coupled to flame atomic absorption spectrometry. Analytica Chimica Acta 2009, 636 (2), 198-204.

[9] Cocozza, C.; D’orazio, V.; Miano, T. M.; Shotyk, W. Characterization of solid and aqueous phases of a peat bog profile using molecular fluorescence spectroscopy, ESR and FT-IR, and comparison with physical properties. Organic Geochemistry 2003, 34(1), 49-60.

[10] Couillard, D. The use of peat in wastewater treatment. Water Research 1994, 28(6), 1261-1274.

[11] Blackford, J. J.; Chambers, F. M. Determining the degree of peat decomposition in peat-based palaeoclimatic studies. International Peat Journal 1993, 5, 7-24.

[12] Henderson, R. E.; Doiron, R. Some Identification Hints for the Field Classification of Peat. In Proceedings of Organic Soils Mapping Workshop, Fredericton, NewBrunswick; Agriculture Canada, Land Resource Research Institute: Ottawa, 1981, 105-110.

[13] Lévesque, M. P.; Mathur, S. P. A comparison of various means of measuring the degree of decomposition of virgin peat materials in the context of their relative biodegradability. Canadian Journal of Soil Science 1979, 59(4), 397-400.

[14] von Post, L. Das genetische system der organogenen bildungen schwedens. International Committee of Soil Science 1924, 22, 287-304.

[15] Wüst, R. A. J.; Ward, C. R.; Bustin, R. M.; Hawke, M. I. Characterization and quantification of inorganic constituents of tropical peats and organic-rich deposits 
from Tasek Bera (Peninsular Malaysia): implications for coals. International Journal of Coal Geology 2002, 49(4), 215-249.

[16] Giovanela, M.; Crespo, J. S.; Antunes, M.; Adamatti, D. S.; Fernandes, A. N.; Barison, A.; Silva, C. W. P.; Guégan, R.; Motelica-Heino, M.; Sierra, M. M. D. Chemical and spectroscopic characterization of humic acids extracted from the bottom sediments of a Brazilian subtropical microbasin. Journal of Molecular Structure 2010, 981(1-3), $111-119$.

[17] Girardello, F. Dissertação de Mestrado, Universidade de Caxias do Sul; Caxias do Sul: Brasil, 2011; 73pp.

[17] Swift, R. S. Method for Extraction of IHSS Soil Fulvic and Humic Acids. In Methods of Soil Analysis; Spark, K. M.; Wells, J. D.; Johnson, B. B., Eds.; Soil Science of Society of American: Madison, 1996, 520p.

[18] Skjemstad, R.; Clarke; P.; Taylor, J. A.; Oades, J. M.; Newman, R. H. The removal of magnetic materials from surface soils. A solid state ${ }^{13} \mathrm{C}$ CP/MAS N.M.R. study. Australian Journal of Soil Research 1994, 32(6), 1215-1229.

[19] Sathishkumar, M.; Pavagadhi, S.; Vijayaraghavan, K.; Balasubramanian, R.; Ong, S. L. Experimental studies on removal of microcystin-LR by peat. Journal of Hazardous Materials 2010, 184(1-3), 417-424.

[20] Fernandes, A. N.; Almeida, C. A. P.; Menezes, C. T. B.; Debacher, N. A.; Sierra, M. M. D. Removal of methylene blue from aqueous solution by peat. Journal of Hazardous Materials 2007, 144(1-2), 412-419. 
[21] López-Buendía, A. M.; Whateley, M. K. G.; Bastida, J.; Urquiola, M. M. Origins of mineral matter in peat marsh and peat bog deposits, Spain. International Journal of Coal Geology 2007, 71(2-3), 246-262.

[22] Kalaitzidis, S.; Christanis, K. Scanning electron microscope studies of the Philippi peat (NE Greece): initial aspects. International Journal of Coal Geology 2003, 54(1), 69-77.

[23] Fernandes, A. N.; Giovanela, M.; Esteves, V. I.; Sierra, M. M. D. Elemental and spectral properties of peat and soil samples and their respective humic substances. Journal of Molecular Structure 2010, 971(1-3), 33-38.

[24] Zaccone, C.; Miano, T. M.; Shotyk, W. Qualitative comparison between raw peat and related humic acids in an ombrotrophic bog profile. Organic Geochemistry 2007, $38(1), 151-160$.

[25] Xu, X. Q.; Hanna, J. V.; Johnson, W. D. Source indicators of humic substances: an elemental composition, solid state ${ }^{13} \mathrm{C}$ CP/MAS NMR and Py-GC/MS study. Applied Geochemistry 2000, 15(7), 1019-1033.

[26] Kuhry, P.; Vitt, D. H. Fossil carbon/nitrogen ratios as a measure of peat decomposition. Ecology 1996, 77, 271-275.

[27] Fernandes, A. N. Tese de Doutorado, Universidade Federal de Santa Catarina; Florianópolis: Brasil, 2007; 127pp.

[28] Francioso, O.; Ciavatta, C.; Montecchio, D.; Tugnoli, V.; Sánchez-Cortés, S.; Gessa, C. Quantitative estimation of peat, brown coal and lignite humic acids using chemical 
parameters, ${ }^{1} \mathrm{H}-\mathrm{NMR}$ and DTA analyses. Bioresource Technology 2003, 88(3), $189-195$.

[29] Sheppard, J. D.; Forgeron, D. W. Differential thermogravimetry of peat fractions. Fuel, 1987, 66(2), 232-236.

[30] Leinweber, P.; Schulten, R.; Horte, C. Differential thermal analysis, thermogravimetry and in-source pyrolysis-mass spectrometry studies on the formation of soil organic matter. Thermochimica Acta 1992, 200, 151-167.

[31] Tiainen, M.; Daavitsainen, J.; Laitinen, R. S. The role of amorphous material in ash on the agglomeration problems in FB boilers. A powder XRD and SEM-EDS study. Energy Fuels 2002, 16(4), 871-877.

[32] Bozkurt, S.; Lucisano, M.; Moreno, L.; Neretnieks, I. Peat as a potential analogue for the long-term evolution in landfills. Earth-Science Reviews 2001, 53(1-2), 95-147.

[33] Stevenson, F. J. Humus Chemistry: Genesis, Composition, and Reactions; John Willey and Sons: New York, 1994; 512pp.

[34] Giovanela, M.; Parlanti, E.; Soriano-Sierra, E. J.; Soldi, M. S.; Sierra, M. M. D. Elemental compositions, FT-IR spectra and thermal behavior of sedimentary fulvic and humic acids from aquatic and terrestrial environments. Geochemical Journal 2004, 38(3), 255-264.

[35] Chapman, S. J.; Campbell, C. D.; Fraser, A. R.; Puri, G. FTIR spectroscopy of peat in and bordering Scots pine woodland: relationship with chemical and biological properties. Soil Biology and Biochemistry 2011, 33(9), 1193-1200. 
[36] Madejová, J.; Komadel, P. Baseline studies of the clay minerals society source clays: infrared methods. Clays and Clay Minerals 2011, 49(5), 410-432.

[37] Pedersen, J. A.; Simpson, M. A.; Bockheim, J. G.; Kumar, K. Characterization of soil organic carbon in drained thaw-lake basins of Arctic Alaska using NMR and FTIR photoacoustic spectroscopy. Organic Geochemistry 2011, 42(8), 947-954.

[38] Sierra, M. M. D.; Giovanela, M.; Parlanti, E.; Esteves, V. I.; Duarte, A. C.; Fransozo, A.; Soriano-Sierra, E. J. Structural description of humic substances from subtropical coastal environments using elemental analysis, FTIR and ${ }^{13} \mathrm{C}$-solid state NMR data. Journal of Coastal Research 2005, 42, 370-382.

[39] Knicker, H. Solid state CPMAS ${ }^{13} \mathrm{C}$ and ${ }^{15} \mathrm{~N}$ NMR spectroscopy in organic geochemistry and how spin dynamics can either aggravate or improve spectra interpretation. Organic Geochemistry 2011, 42(8), 867-890.

[40] Dignac, M. F.; Knicker, H.; Kögel-Knaber, I. Effect of N content and soil texture on the decomposition of organic matter in forest soils as revealed by solid-state CPMAS NMR spectroscopy. Organic Geochemistry 2002, 33(12), 1715-1726.

[41] van Bergen, P. F.; Hatcher, P. G.; Boon, J. J.; Collinson, M. E.; de Leeuw; J. W. Macromolecular composition of the propagule wall of Nelumbo nucifera. Phytochemistry 1997, 45(3), 601-610. 
Table Captions:

Table 1 Elemental composition, atomic ratios and ash contents of the studied peat samples.

\begin{tabular}{|c|c|c|c|c|c|c|c|c|}
\hline Samples & $\mathrm{C}(\%)$ & $\mathrm{H}(\%)$ & $\mathrm{N}(\%)$ & $\mathrm{S}(\%)$ & $\mathrm{O}(\%)^{\mathrm{a}}$ & $\mathrm{H} / \mathrm{C}^{\mathrm{b}}$ & $\mathrm{C} / \mathrm{N}^{\mathrm{c}}$ & Ash content (\%) \\
\hline PS-1 & $44.22 \pm 0.26$ & $4.15 \pm 0.08$ & $1.60 \pm 0.03$ & 0.00 & 50.02 & $1.12 \pm 0.03$ & $32.15 \pm 0.52$ & $9.02 \pm 0.17$ \\
\hline PS-2 & $56.49 \pm 0.05$ & $5.07 \pm 0.06$ & $1.31 \pm 0.04$ & 0.00 & 37.13 & $1.07 \pm 0.01$ & $50.17 \pm 1.34$ & $7.15 \pm 0.26$ \\
\hline
\end{tabular}

${ }^{\text {a }}$ By difference of mean values;

${ }^{\mathrm{b}} \mathrm{H} / \mathrm{C}=[(\% \mathrm{H} / 1.008) /(\% \mathrm{C} / 12.01)]$

${ }^{\mathrm{c}} \mathrm{C} / \mathrm{N}=[(\% \mathrm{C} / 12.01) /(\% \mathrm{~N} / 14.00)]$

Table 2 Results of the TG analysis of the studied peat samples.

\begin{tabular}{|c|c|c|c|c|c|}
\hline \multirow{3}{*}{ Samples } & \multicolumn{4}{|c|}{ Weight loss (\%) } & \multirow{3}{*}{$\begin{array}{c}\text { Residual mass at } \\
\quad 900^{\circ} \mathrm{C}(\%)\end{array}$} \\
\hline & First stage & Second stage & Third stage & Fourth stage & \\
\hline & $25-155^{\circ} \mathrm{C}$ & $155-380^{\circ} \mathrm{C}$ & $380-615^{\circ} \mathrm{C}$ & $615-900^{\circ} \mathrm{C}$ & \\
\hline PS-1 & 1.0 & 24.7 & 20.4 & 11.6 & 42.3 \\
\hline PS-2 & 1.8 & 23.4 & 25.1 & 15.9 & 33.8 \\
\hline
\end{tabular}


Table 3 Integrated areas of the main signal regions of the ${ }^{13} \mathrm{C}$ NMR spectra of the studied peat samples.

\begin{tabular}{lcccccc}
\hline Samples & $\mathrm{R}_{1}$ & $\mathrm{R}_{2}$ & $\mathrm{R}_{3}$ & $\mathrm{R}_{4}$ & $\mathrm{R}_{5}$ & $\mathrm{R}_{6}$ \\
& $0-65 \mathrm{ppm}$ & $65-110 \mathrm{ppm}$ & $110-140 \mathrm{ppm}$ & $140-160 \mathrm{ppm}$ & $160-190 \mathrm{ppm}$ & $190-220 \mathrm{ppm}$ \\
\hline PS-1 & 51.5 & 27.5 & 11.1 & 3.03 & 4.83 & 2.04 \\
PS-2 & 48.4 & 26.3 & 14.8 & 5.29 & 3.70 & 1.51 \\
\hline
\end{tabular}




\section{Figure Captions:}

Fig 1. Localization of the sampling points in the peat bog of Balneário Arroio do Silva (Santa Catarina State, Brazil).

Fig. 2 SEM micrographs of the PS-1 sample. Magnification level of: (a) $100 \times$, (b) $500 \times$, (c) $1000 \times$.

Fig. 3 SEM micrographs of the PS-2 sample. Magnification level of: (a) $100 \times$, (b) $500 \times$, (c) $1000 \times$.

Fig. 4 TG (-) and DTG (---) curves of the peat samples.

Fig. 5 XRD diffractograms of the peat samples (where $\mathrm{C}=$ clay, $\mathrm{F}=$ feldspar; $\mathrm{Q}=$ quartz).

Fig. 6 FT-IR spectra of the peat samples.

Fig. 7 Solid-state ${ }^{13} \mathrm{C}$ NMR spectra of the peat samples. 

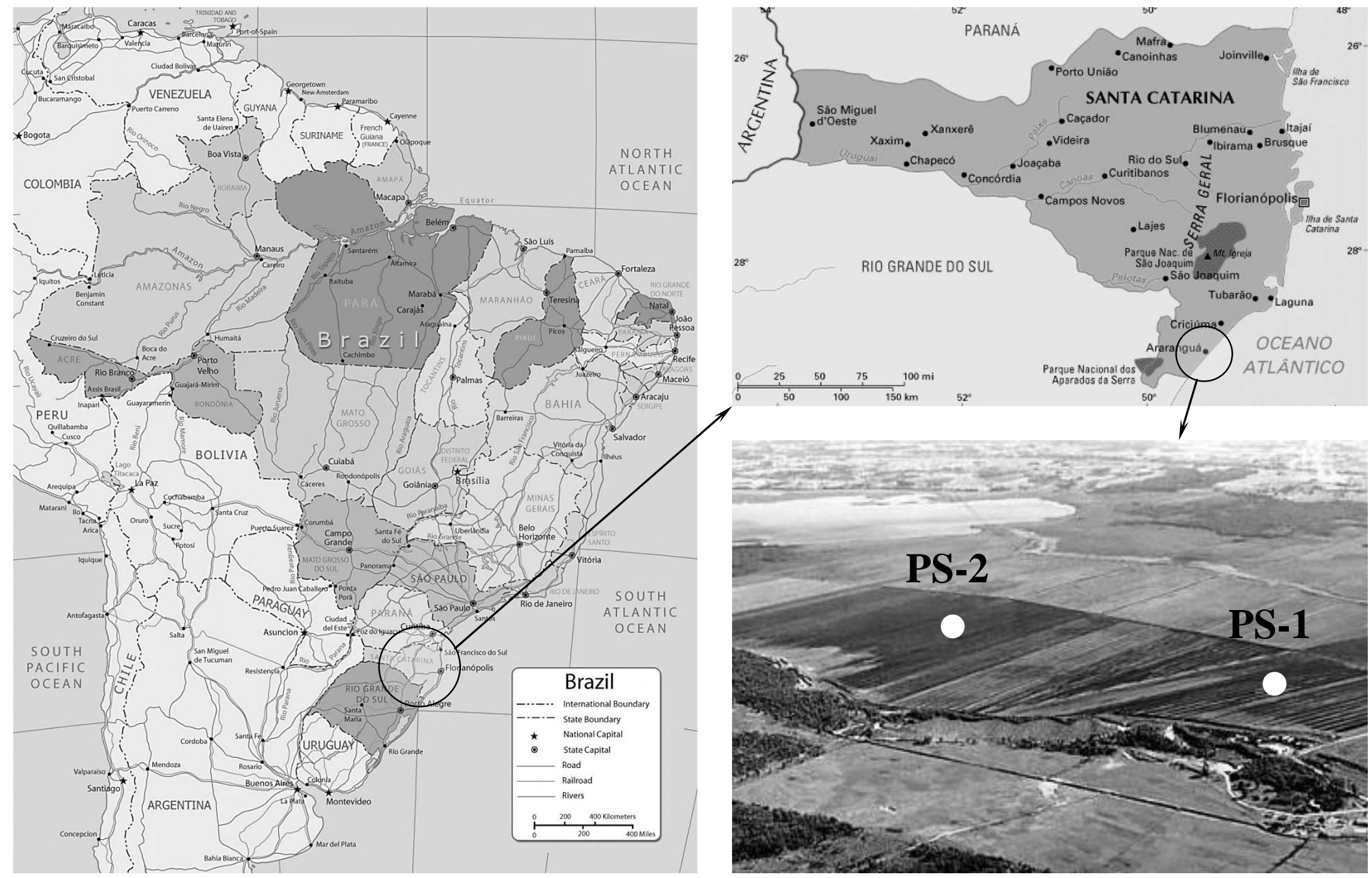

Fig. 1 Localization of the sampling points in the peat bog of Balneário Arroio do Silva (Santa Catarina State, Brazil). 


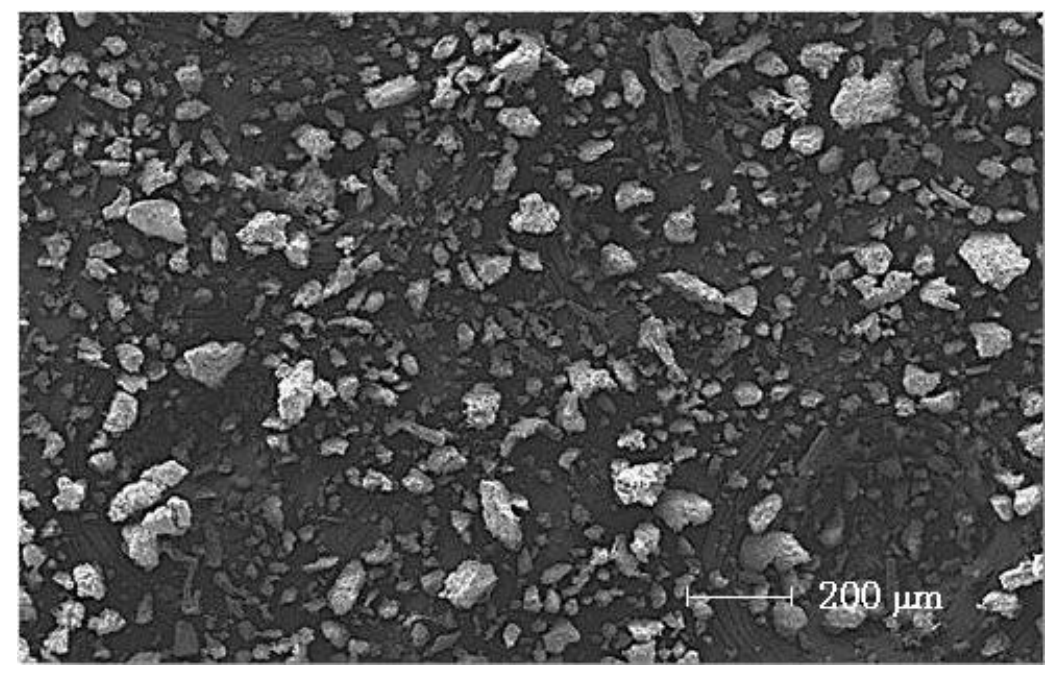

(a)

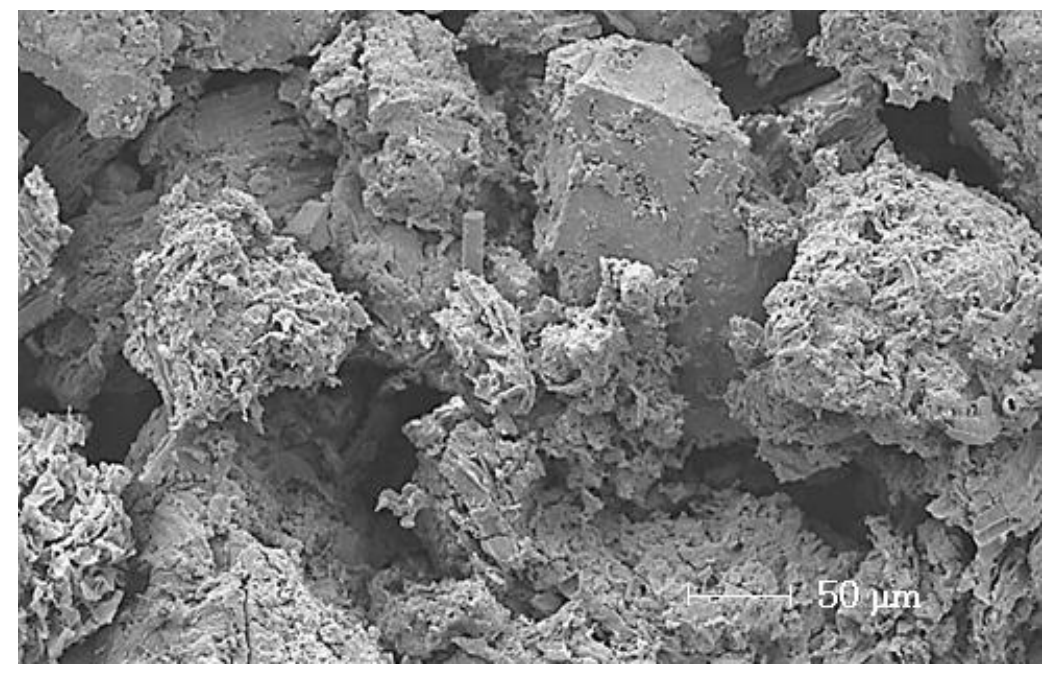

(b)

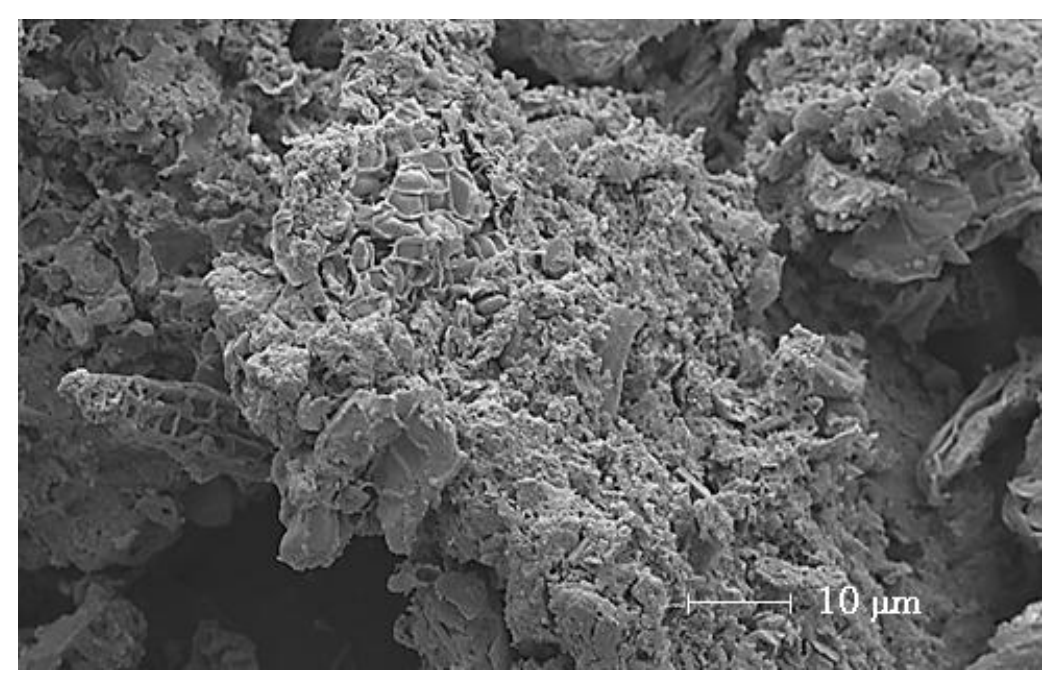

(c)

Fig. 2 SEM micrographs of the PS-1 sample. Magnification level of: (a) $100 \times$, (b) $500 \times$, (c) $1000 \times$. 


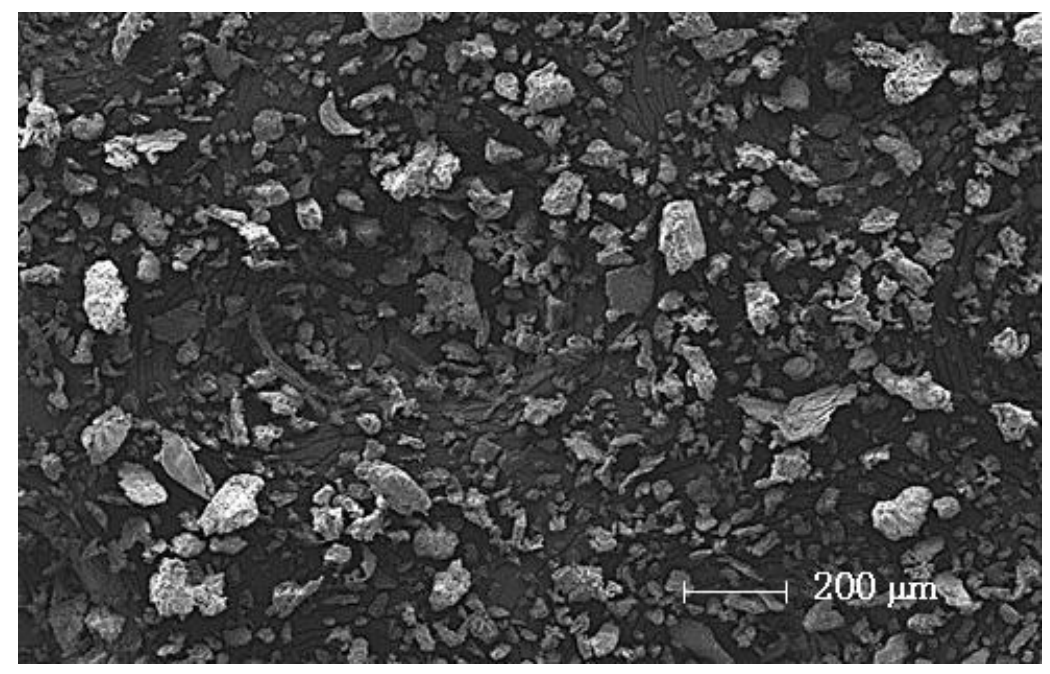

(a)

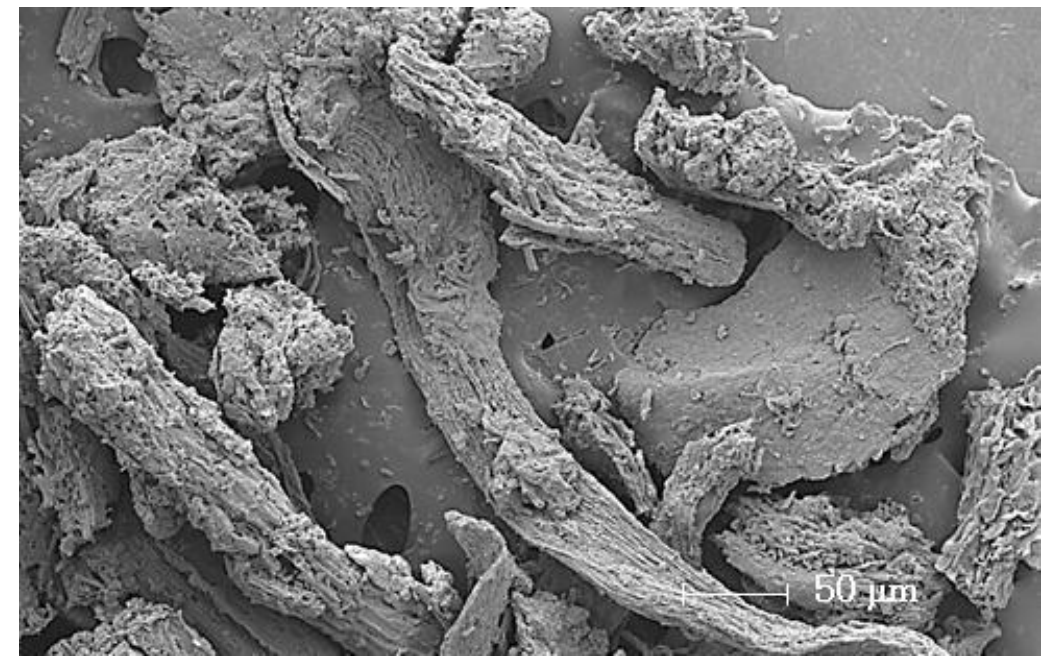

(b)

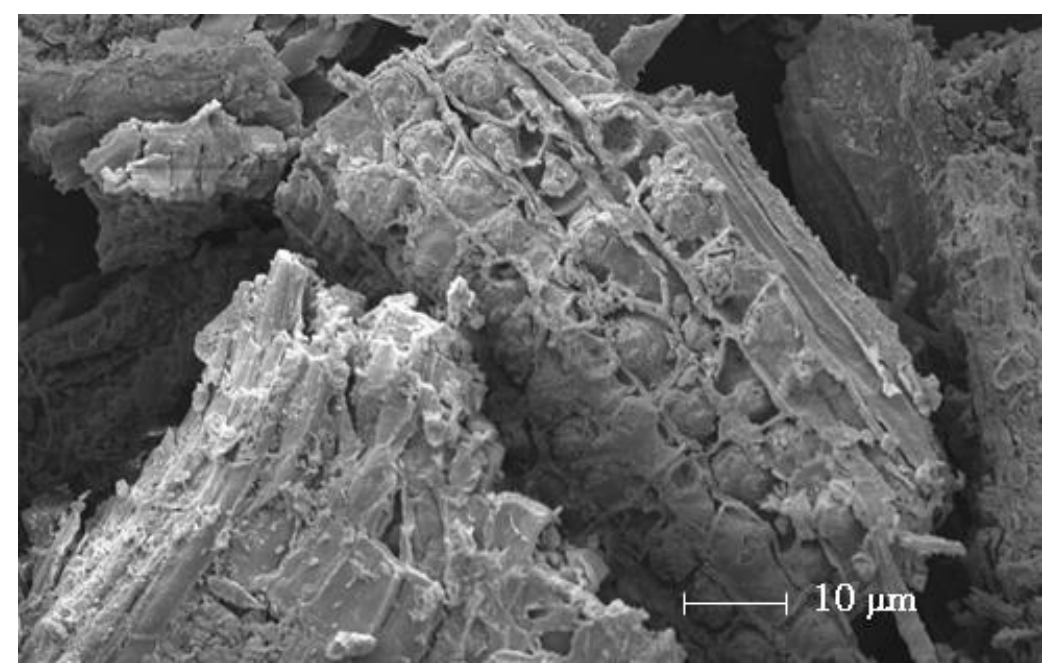

(c)

Fig. 3 SEM micrographs of the PS-2 sample. Magnification level of: (a) $100 \times$, (b) $500 \times$, (c) $1000 \times$. 

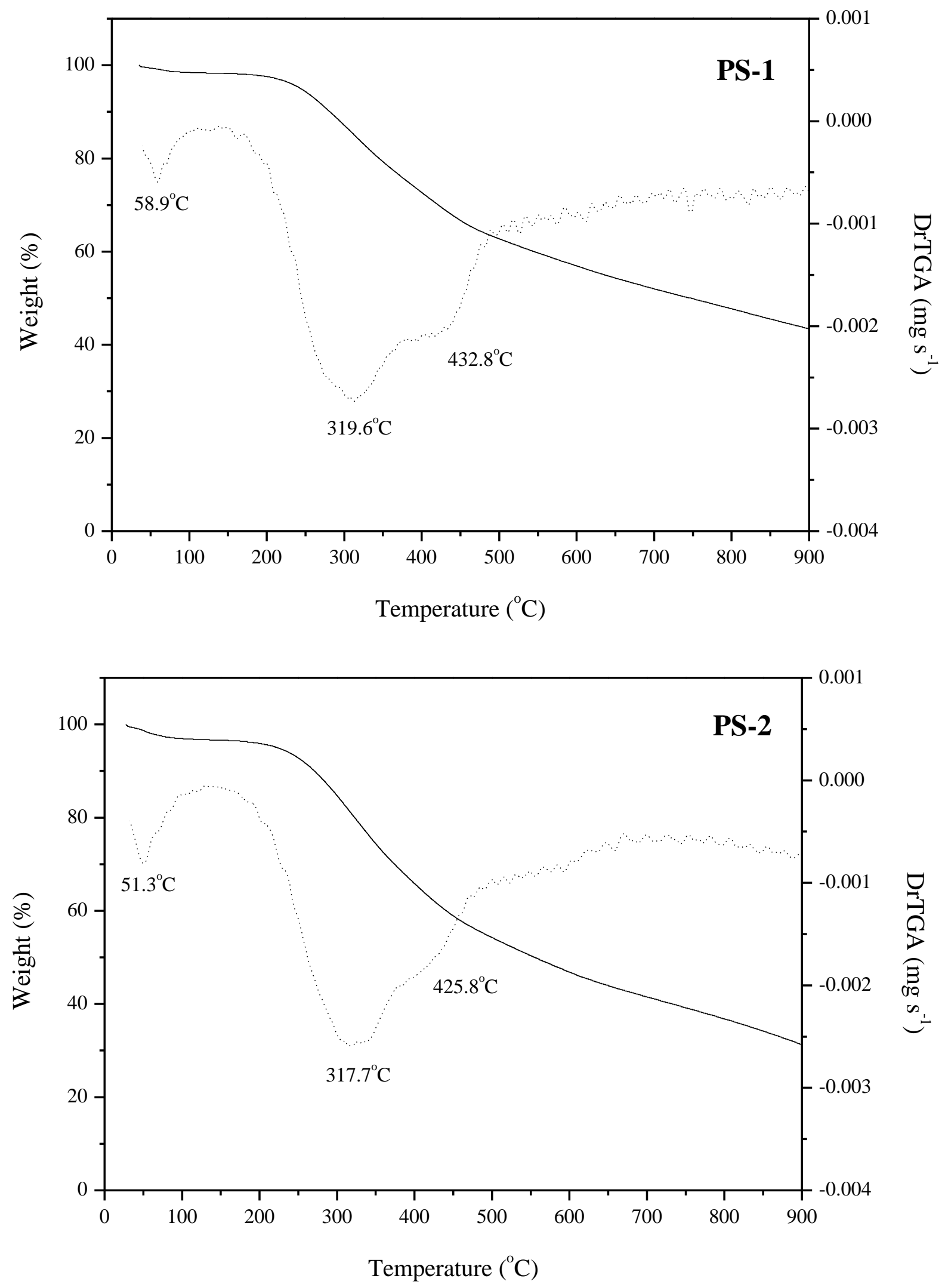

Fig. 4 TG (-) and DTG (---) curves of the peat samples. 


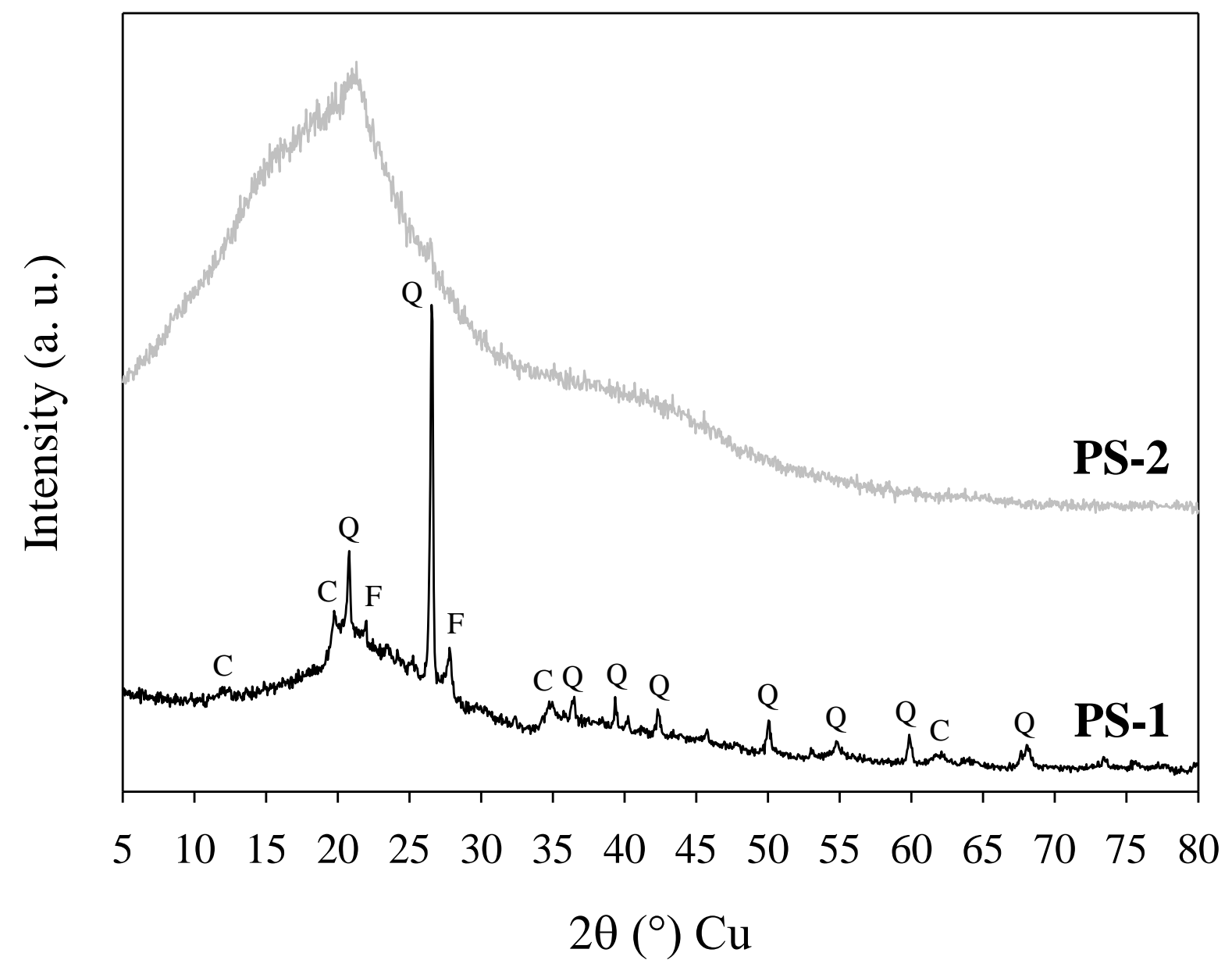

Fig. 5 XRD diffractograms of the peat samples (where $C=$ clay, $F=$ feldspar; $Q=$ quartz). 


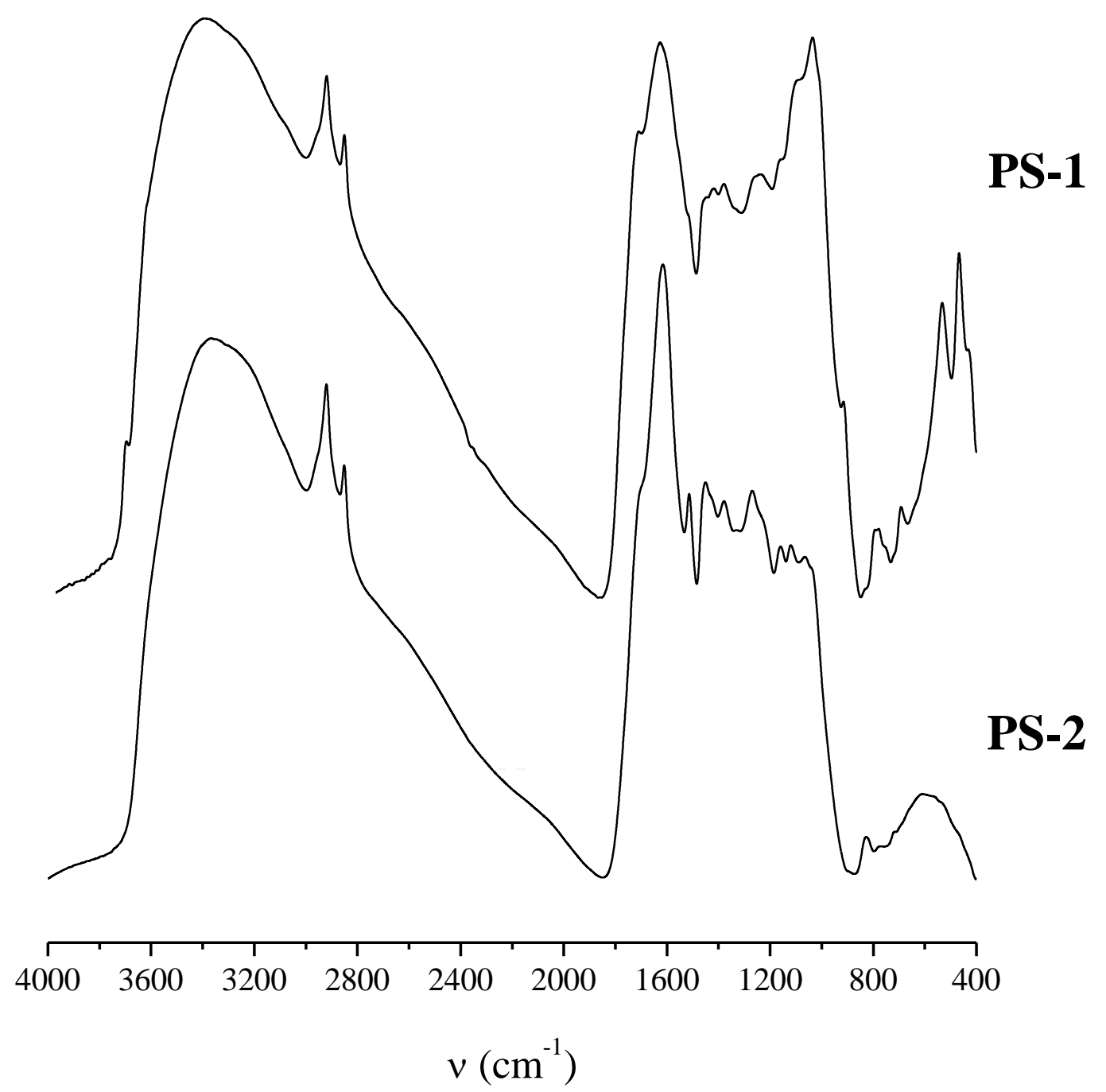

Fig. 6 FT-IR spectra of the peat samples. 

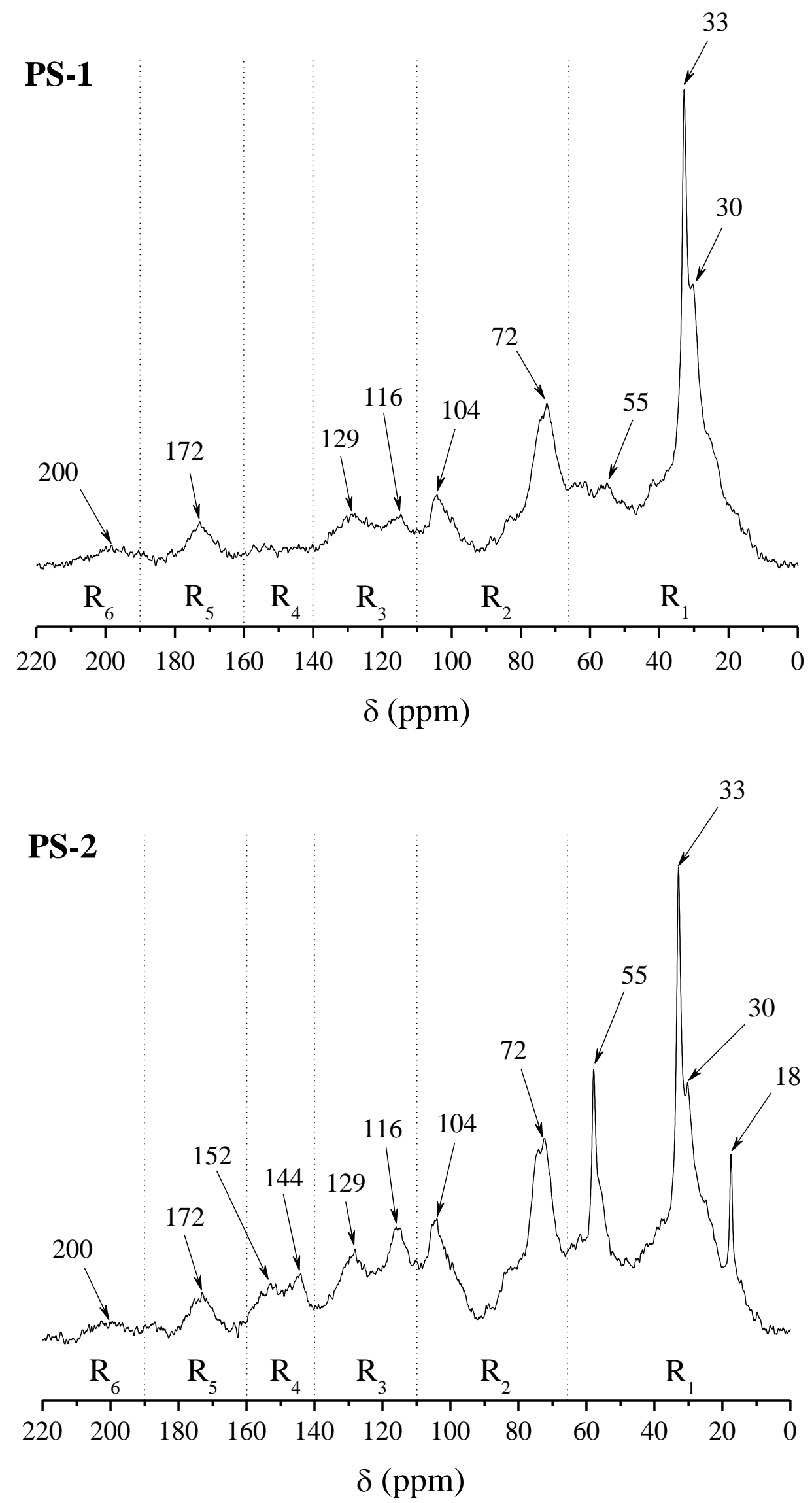

Fig. 7 Solid-state ${ }^{13} \mathrm{C}$ NMR spectra of the peat samples. 